\title{
PPP2R1A wt Allele
}

National Cancer Institute

\section{Source}

National Cancer Institute. PPP2R1A wt Allele. NCI Thesaurus. Code C92537.

Human PPP2R1A wild-type allele is located in the vicinity of 19q13.41 and is approximately $37 \mathrm{~kb}$ in length. This allele, which encodes serine/threonine-protein phosphatase $2 \mathrm{~A} 65 \mathrm{kDa}$ regulatory subunit $\mathrm{A}$ alpha isoform protein, plays a role in coordinating the assembly of the protein phosphatase 2A heterodimer. Mutation of the gene may be associated with ovarian clear cell carcinoma. 